Accepted for publication in Environment and History, 2019.

\title{
UNDER THE VOLCANO: MOUNT MAYON AND CO-VOLCANIC SOCIETIES IN THE PHILIPPINES
}

Greg Bankoff

University of Hull

Email: G.Bankoff@hull.ac.uk

\begin{abstract}
Rich volcanic soils have long attracted human settlements, which have traded the risk of eruption against the benefits of higher agricultural yields. Yet little research has been done on how societies have normalised the risks and adapted to living in proximity to volcanoes, or how those modifications, in turn, might have influenced the effects of eruptions and their consequent hazards. In short, people have co-evolved with volcanoes to create 'co-volcanic societies’. By looking closely at the Philippines and focusing on one region of southern Luzon around Mount Mayon, this article addresses the question of how people and the volcano have 'co-adapted’ to living in proximity to one another over time. It also suggests that to make societies more resilient to volcanic hazards, a better understanding of this relationship is required not only to improve current disaster risk reduction policies but even to inform everyday urban planning and civil engineering decisions.
\end{abstract}

\section{KEYWORDS}

co-volcanic societies, volcanoes, Mount Mayon, Philippines

Volcanoes are one of the most powerful forces of nature. Single eruptions have devastated cities, modified landscapes and even altered climates. Historical case studies demonstrate the devastating impact of eruptions. The eruption of Tambora (Indonesia) in 1815 perhaps 
changed the course of European history (the Battle of Waterloo) and triggered the 'year without a summer' ${ }^{1}$ In 1902, pyroclastic density currents killed over 28,000 people and destroyed the city of St Pierre, the 'Paris of the Caribbean,' during the eruption of Mount Pelée (Martinique). The lahars from Mount Pinatubo (Philippines) in 1991, the second largest terrestrial eruption of the twentieth century, altered the topography of Central Luzon. Since 1900, nearly 5 million people have been affected by volcanic events and over 91,000 people have died directly from ash asphyxiation, thermal injuries from pyroclastic density currents, and trauma. Moreover, these figures are unlikely to reflect the true extent of casualties given the inconsistent reporting of such events, particularly with respect to the number of injured and affected. ${ }^{2}$ Approximately 9 per cent of the global population or more than 500 million people now live within the potential exposure range of the 550 or so active volcanoes that have erupted within the last 10,000 years. ${ }^{3}$ As populations continue to grow, an increasing number of urban centres located near active volcanoes will place more people, property and infrastructure at risk than ever before.

Despite the self-evident dangers of living too close to a volcano, fertile soils have long attracted human settlements, whose residents have traded the risk of an eruption against the advantage of higher agricultural yields. As yet, however, little research has been done on the manner in which societies have normalised the risks and adapted to living in close proximity to volcanoes: how communities have co-evolved with volcanoes, balancing the benefits of rich soils and good harvests against the threat of sudden death and destruction, and, by their activities, modifying the landscape and so affecting the course of eruptions, to create what can be called 'co-volcanic societies'. Through history, people have learnt to live with volcanoes in different ways. Some people have 'moved' their city to safer locations. In Costa Rica, the capital was transferred from Cartago (founded 1563) to San José in 1823 because of the constant destruction wrought by Irazú Volcano. Other people have sought to 
appease volcanoes by deifying them. Hawaiian islanders and the Maori of Aotearoa/New Zealand elaborated religious practices around their daily activities as a form of psychological accommodation to the danger of living with volcanoes. Still others have tried to structurally modify the landscape through feats of engineering: the Romans in the fifth century BCE constructed a tunnel to regulate the level of the volcanic Lake Albano in Italy. ${ }^{4}$

By looking closely at the Philippines, ranked as the second most dangerous country in the world to live in, and focusing on one region of southern Luzon around Mount Mayon, the most active volcano in the archipelago, this article addresses the question of how people have co-adapted to living in close proximity to a volcano over time. ${ }^{5}$ It proposes two related propositions: that communities and cultures are shaped by living with the constant threat of volcanic eruptions, and that the course (not the type or timing) of such eruptions, particularly the flow of lava and lahars are altered by human modifications of the surrounding landscape. It also suggests that to make society more resilient to volcanic hazards, a better understanding of this relationship is required not only to improve current disaster risk reduction policies but even to inform everyday urban planning and civil engineering decisions. The Philippines provide just such a landscape of risk from which to explore the concept of 'co-volcanic societies’. The country has 23 active volcanoes, has experienced at least one killer eruption claiming more than 1,000 lives each century for the last 200 years (Mayon Volcano in 1814 and Taal Volcano in 1911) and, in Mount Pinatubo in 1991, has been subjected to the largest eruption ever to have affected a densely populated area in the archipelago. Just as Popocatepetl and Iztaccihuatl cast their shadows over the protagonists' lives in Malcolm Lowry's masterful novel (1947) of the same name, so have the communities around Mount Mayon, over time, learnt to live ‘under the volcano’. 
Scholars have long been intrigued by the idea that people who are frequently exposed to hazard adapt their behaviour to accommodate risk and that these patterns can become embedded to some extent in cultures over time. Harry Moore is credited with first coining the term 'disaster subculture' to describe 'those adjustments, actual and potential, social, psychological and physical, which are used by residents of such areas in their efforts to cope with disasters which have struck or which tradition indicates may strike in the future' ${ }^{6}$ Moore was writing about how people who lived in coastal communities acted as Hurricane Carla hit Texas in September 1961, and he explained their behaviour as pertaining to a 'hurricane subculture'. Moore never went on to fully formulate his ideas; this was left to a research paper by Dennis Wenger and Jack Weller written nearly a decade later. Based on research carried out in a number of communities across the United States regularly affected by flooding and hurricanes, they sought to uncover the existence of disaster subcultures through indices that showed 'the perpetuation of successful patterns of adaptation to the disaster context through socialization'. ${ }^{7}$ Rather than viewing disaster subcultures as special arrangements apart from the general culture of the community that are resorted to in times of need, more in the way Moore argued, Wenger and Weller regard the subcultural traits that evolved out of the experience of disasters as fully integrated into the dominant non-disaster culture, able to be passed down from one generation to the next, and as transmissible to new community members. They went on to identify three factors that appear to be crucial to the emergence of a disaster subculture within a community: that a hazard has to be repetitive, of such a nature as to allow a period of forewarning, and that its consequences inflict significant damage to human and material resources. ${ }^{8}$

As the factors identified by Wenger and Weller indicate, these scholars were particularly concerned with recurring hazards such as hurricanes/typhoons and floods that 
promoted cultural adaptations in affected communities through the regularity of their occurrence. Earthquakes, too, if communities are located on tectonic faults, also satisfy these criteria: they occur at frequent if irregular intervals, people living in seismically active areas know they are at risk, and the consequences inflict significant losses in terms of mortality and material damage. ${ }^{9}$ The historical frequency of earthquakes in Japan, for instance, has shaped the material and symbolic culture of that society to such an extent that Greg Clancey dubbed it an 'earthquake nation'. ${ }^{10}$ With reference to the 1999 Kocaeli (Izmit) earthquake in western Turkey, Jacqueline Homan and Warren Eastward recognise a ‘seismic culture’ comprised of very specific adaptations to the hazard of earthquakes. They define seismic cultures as those having: 'The knowledge (both pragmatic and theoretical) that has built up in a community exposed to seismic risks through time' ${ }^{11}$

This knowledge may be expressed in a society’s architectural forms and building techniques, as in the case of Japan and Turkey, or it may be embedded in a community's local knowledge and oral traditions. In non-literate societies or where literacy is the preserve of the elite, important evidence on the history of past disasters and communities' successful coping practices may be embedded in the myths, legends and rituals passed down through the generations. While these narratives may constitute a record of a culture's memory of past geological events such as major floods, earthquakes and volcanic eruptions, the information is often expressed in metaphorical language to ensure its faithful recollection and dissemination, and so requires careful decoding of its symbolism. ${ }^{12}$ It is also often a mechanism for attributing meaning and responsibility to some external source, whether it be a god or hero, for an event beyond the human power to comprehend or control, and so provides a culturally acceptable explanation to reduce collective trauma. ${ }^{13}$

Whether cultural adaptation takes place, however, when the hazard occurs less frequently such as in the case of a volcano is a more difficult question to answer. While a 
volcano's dominance of a surrounding landscape is a constant visible reminder to those who live around its base of potential risk, the infrequency with which volcanoes erupt, with some lying dormant for centuries, usually creates a sense of complacency among the surrounding population, who forget the threat to which they are exposed. For instance, the explosive eruption of Mount Pinatubo in 1991 occurred after some 400 to 500 years of inactivity. These cataclysmic eruptions, however, often provide little opportunity for cultural learning and frequently lead to the abandonment of the immediate area and the relocation of the population to a new site. ${ }^{14}$ Other volcanoes, however, erupt with much greater frequency: Kilauea on Hawaii is the world's most active volcano, followed by Etna in Italy, and Piton de la Fournaise on the island of Réunion. As a consequence, local populations there have had to adapt to living with the likelihood that an eruption might occur at any time and take steps to mitigate the risk. Over time, these measures become embedded in local cultures.

In his study of villagers' adaptation to living on the slopes of Mount Merapi, the most active volcano in Indonesia, for instance, Michael Dove noted the way that the local agricultural economy not only 'naturalised' but actually utilised volcanic perturbations to the extent that they could be said to have created 'a culture of volcanic hazard'. ${ }^{15}$ Moreover, he argues that even the concept of natural hazards likely co-evolved with the hazards themselves so that natural perturbations and their cultural construction have historically developed in tandem. ${ }^{16}$ The more recent focus on interdisciplinary research has also led to what Katherine Donovan calls the emergence of 'social volcanology' as a means of reducing volcanic risk by an examination of local societies. ${ }^{17}$

The necessity for such research in the Philippines is pressing given that more than 80 per cent of the total national population live in close proximity to an active volcano, one of the highest concentrations of people in the world. ${ }^{18}$ City dwellers, however, all too soon 
forget the customary lore and local practices that helped ensure the safety of their rural forebears, and so put themselves and their families at greater risk when eruptions occur.

An archipelago located off Indochina in the western Pacific, the land area of the Philippines totals little more than 300,000 square kilometres spread over more than 7,000 islands. The archipelago lies on the Pacific Rim of Fire, a 48,000 kilometre long horseshoe rimming the Pacific Ocean from Indonesia to Chile where over 75 per cent of all volcanoes in the world are located and where nearly 90 per cent of the world's earthquakes happen. Wedged between the much larger Pacific and Eurasian tectonic plates, the continuous collision and subduction of the small Philippine Sea Plate make the archipelago an area of extreme geophysical activity. ${ }^{19}$ Disasters, therefore, are simply a fact of life for most Filipinos. A socially and economically vulnerable population of more than 100 million where over one in four families live below the poverty line combines with one of the world's most hazardous landmasses to make disasters there a 'frequent life experience'. ${ }^{20}$

\section{MAYON VOLCANO}

Volcanic activity has been frequent and destructive in the Philippines. Currently there are 23 volcanoes in the archipelago listed by the Philippine Institute of Volcanology and Seismology (PHIVOLCS) as active. Active volcanoes are those with either a documented eruption within historical times (that is, the last 600 years) or where an eruption can be shown to have taken place within the last 10,000 years based on analyses of datable materials. ${ }^{21}$ The two most active volcanoes in the country are Taal Volcano and Mayon Volcano. Taal is located in central Luzon less than 50 kilometres from the densely populated capital city of Manila, and it has erupted over thirty times since 1572, most notably in 1911, when it killed 1,300 people. Its eruptions are sometimes accompanied by tsunami-like waves as the water in the caldera 
from which the volcano rises often inundates the surrounding countryside, flooding towns and settlements. ${ }^{22}$ The archipelago's most active volcano, however, is Mount Mayon in Albay, the second most southerly province on the main island of Luzon. Mayon is a stratovolcano with a perfectly shaped cone and a basal circumference of $63 \mathrm{~km}$ that rises to an elevation of over 2600m. Known locally in the Bikol language as Daragang Magayón (the Beautiful Lady), the volcano has erupted over fifty times since February 1616, when a passing Dutch explorer, Joris van Spilbergen, recorded an eruption in his ship’s log and described the mountain as ‘constantly burning' and being 'full of sulphur and such-like things'. ${ }^{23}$

FIG > Figure 1 near here

However, there are few recorded accounts of eruptions prior to 23 October 1766, when 'a horrendous explosion’ caused a river of molten lava 'fathoms-wide’ to flow down the sides of the volcano and devastate the town of Malinao and the surrounding villages, killing many hundreds of people. ${ }^{24}$ Undoubtedly, there were many other eruptions before the nineteenth century that have yet to be documented; the fifty or so subsequent events suggest that the volcano has erupted frequently and there is little reason to suppose that activity in the seventeenth and eighteenth centuries was any different. Subsequent to the eruption of Mayon in 1800, however, there is a detailed historical record of volcanic activity. Most of these eruptions have been fairly minor with a volcanic explosivity index (VEI) of two or less. Despite this low VEI, the volcano has often been in a continuous eruptive state for decades at a time. In the 1850s, for example, there were two minor eruptions of ash in 1851, a major eruption on 13 July 1853 that killed 33 people and destroyed many houses, another on 22 March 1855, and yet another in 1857 that produced so much ash that it reportedly killed all 
the bees in the region. The volcano was active 'almost without interruption' in 1858, while a resplendent glowing cone lit up the night sky on most clear nights between 1859 and $1860 .^{25}$

On still other occasions, however, the volcano vented its full fury. The deadliest recorded eruption took place on 1 February 1814. An immense column of smoke and ash rose suddenly from the summit and spread rapidly, completely darkening the sky while a torrent of fire, lava and incandescent stones flowed down the southern flanks of the volcano 'devastating, burning and consuming everything in its path'. ${ }^{26}$ According to contemporary descriptions, the death toll reached 1,200, and three towns were completely devastated and two others partially destroyed. Another major eruption began on 23 June 1897 and lasted for four days. Huge columns of dust-laden vapour escaped from the crater, while great quantities of molten lava and incandescent rocks poured down its slopes. Volcanic bombs and lapilli (rock fragments) were thrown high into the sky as flashes of lightning zigzagged about the cone. Many settlements at the foot of the volcano were destroyed completely and the town centre of Libog (present-day Santo Domingo) was only saved by what was described as a 'ridge' that retained the flow of lava within the preexisting channel of the Basud River. An eyewitness account suggests that an accompanying pyroclastic surge overwhelmed some women as they dried their hair out the windows, leaving their bodies to be discovered in this position. ${ }^{27}$ Ash reportedly fell over an 80 kilometre radius, while the volcano's subterranean rumblings were heard as far afield as Manila. Reliable estimates place the number of dead at approximately 200 people. ${ }^{28}$ Both these eruptions were larger with a VEI of at least four. ${ }^{29}$ Eruptions in the twentieth century have been smaller, only reaching a VEI of 3 (1984), but have still been destructive. ${ }^{30}$ There were few or no casualties from the eruption that began on 10 September 1984, but PHIVOLCS considered it prudent to order an evacuation of more than 73,000 people from the danger zone. During the more recent eruption of 3 February 1993, a pyroclastic density current sped downhill at approximating 300 kilometres an hour, 
catching many farmers in their fields and killing 77 people as well as causing losses to farmland, crops, fisheries and wildlife. ${ }^{31}$

People living within close proximity to the volcano are also at risk from lahars, even when an eruption is not in progress. The loose-lying debris from the continuous volcanic activity that covers the mountain's slopes pose their own dangers and can be suddenly unleashed by the torrential rains of passing tropical storms or typhoons. ${ }^{32}$ This material can flow with considerable volume; boulders are usually transported in debris flows several metres deep, though much shallower depths are able to upset the equilibrium of even relatively large rocks several metres in diameter. Once set in motion, however, there is nothing to stop the descent of these boulders until they reach the low depressions at the base of the mountain or roll into the Gulf of Albay.

There are, at least, three documented accounts when heavy rainfall caused major loss of life. The first great disaster of this kind happened in October 1776 when thousands of people were reported to have died, although there are no precise mortality figures. ${ }^{33}$ The second occasion is often erroneously attributed to an actual eruption of Mayon Volcano on 31 October 1875. A close reading of the accounts, however, suggests instead that the probable cause of the 1,500 deaths were the lahars unleashed by the rainfall of a passing typhoon. Quite apart from the number of casualties, the mudflows devastated an area of farmland greater than in many previous eruptions. ${ }^{34}$ The result on both these occasions was one of desolation, leaving behind 'a mere expanse of bowlders [sic] and sand with pieces of wood and branches of twigs to mark the place where once was a field, a garden, or a thriving community'. ${ }^{35}$

Lahars remained a constant menace, threatening sudden death to communities throughout the twentieth century. Leopoldo Faustino, assistant chief of the Division of Geology and Mines, warned of just such another impending tragedy in a letter to the 
provincial governor of Albay, Mariano Locsin, shortly after the eruption in June 1928. After visiting the volcano, he wrote that there was a danger 'at the present time from the fragmental materials lying unstable on the slopes of the volcano, which with the coming rains may sweep down the mountain sides in torrential flood', and urged that the inhabitants of settlements in their path be warned of the danger. ${ }^{36}$ In November 2006, Typhoon Reming (international codename Durian) did just that as it swept through the Bikol provinces, dumping over 460 millimetres of rain on the sides of the volcano and causing massive lahars that officially killed 754 people but unofficially perhaps as many as 1,200, and affected 1.54 million more. It also devastated the surrounding rice fields and coconut plantations. ${ }^{37}$

To the inhabitants of the province of Albay, volcanic eruptions are not infrequent events that occur at intervals of two or three centuries. Instead, eruptions are just another thing that locals have had to learn to live with and have come to expect as necessarily a part of the daily routine of life 'under the volcano'. At the same time, the constant and growing human activity around the base of the volcano has reshaped the environment over the centuries to such an extent that it affects the manner in which eruptions unfold, influencing the direction and extent of lava flows and lahars. This cultural adaptation on the one hand, and this physical restructuring of the landscape on the other hand, has led to the emergence of a co-volcanic society around Mayon Volcano.

\section{MAYON VOLCANO’S EFFECTS ON SOCIETY}

As might be expected from so much volcanic activity and plentiful rainfall throughout the year, the plains of Albay are very green and fertile. In fact, the four provinces of the Bikol region were historically considered among ‘the richest on Luzon’ due to their agricultural wealth. ${ }^{38}$ From Mayon's summit, according to Faustino, who climbed its slopes on his visit to 
the volcano in 1929, 'Land and sea, fields and forests, villages and towns with their churches and government buildings stretch out in diminutive form as far as the eye can see'. ${ }^{39}$ Volcanic soils or andisols cover less than 1 per cent of the world's surface yet they support 10 per cent of the world's population, including some of the highest human population densities. The fertility of volcanic soil lies partly in its non-crystalline mineral content, which reacts favourably with growing organic matter, and partly in a powdery consistency that retains a high amount of water beneficial to plant growth. ${ }^{40}$ This soil is the result of accumulated volcanic ash that follows eruptions and forms a nutrient-rich layer that facilitates plant growth and agriculture as long as the depth does not exceed $15 \mathrm{~cm}$. If the ash is too deep, however, the cinder-mulch leads to an imbalance of minerals and adversely affects the health of plants and animals. ${ }^{41}$

Soil apart, the regularity of eruptions also has had a dramatic impact on the surrounding vegetation, affecting the distribution and type of plants, especially on the volcano’s flanks. The entire summit of Mayon was reportedly ‘entirely barren’ when Fedor Jagor, the German naturalist and explorer, climbed the volcano in 1859/60. ${ }^{42}$ Yet by 1929 , Mayon's northern and western slopes were swathed in vegetation almost to its tip, with trees up to 50 centimetres in diameter heavily covered with epiphytes, suggesting that no heavy flows of lava or lahars had taken this direction for many years. At the same time, however, the southern and eastern sides of the volcano were practically barren, composed of nothing more than sand and boulders set to slide at every opportunity. Only the lower slopes were covered by cogan and other grasses, and an occasional patch of raspberries. ${ }^{43}$ In the surrounding plains, on the other hand, the andisols, the rich volcanic mulch, were very conducive to subsistence and, later in the nineteenth century, commercial agriculture. In particular, Albay had a thriving trade in abaca (Musa textilis), or Manila hemp, used extensively for rigging in sailing ships. Along with coconut trees (Cocos nucifera), much of 
the region's wealth was invested in these two exports. ${ }^{44}$ Though generally beneficial to agriculture, in the short term, eruptions could have serious consequences. Showers of dust and ash reach distances of over 40 kilometres, turning the leaves of abaca plants brown and wilting the fronds of coconut trees, often killing them. ${ }^{45}$ The wind direction is crucial in determining the extent of the devastation, even blasting the windward side of tree trunks and bamboo, while leaving the lee side green and apparently unharmed. However, this damage is usually only of a temporary nature. ${ }^{46}$ Captain Arlington U. Betts of the US Army, who later rose to become governor of Albay, described how the land that had 'looked dead' at the end of March 1900, with volcanic ash covering all vegetation, had, following the rains, been turned 'within a few weeks' into 'the most beautiful green brilliance imaginable' ${ }^{47}$

While the volcano's effect on the region's soils and vegetation may be its most apparent impact, attracting population to cultivate the land under its shadow, Mayon has exerted an even more profound influence on the rhythm of daily life and the spatial patterns of human settlement. Living in close proximity to the volcano has required that people be ready to evacuate at a moment's notice and be constantly reading the signs forewarning of an impending eruption. Warnings such as micro earthquakes, volcanic tremors, subterranean rumblings, ground deformation and signs of fire in the cone at night have often preceded an eruption. ${ }^{48}$ The town of Libog, for instance, was 'more or less deserted' prior to the eruption of 27 June 1928 as its inhabitants had heeded the signs and had evacuated. ${ }^{49}$ Sometimes, these warnings began weeks beforehand, spreading terror amongst local residents and persuading entire communities to flee and leave whole towns deserted 'for more than a month' at a time. ${ }^{50}$ At least 5,000 'panic-stricken' people reportedly abandoned their homes near the base of the volcano in 1928 and moved to places of safety such as the refugee camps set up under the supervision of the Red Cross. ${ }^{51}$ Still, this was preferable to the danger that otherwise came upon people caught unawares. Pyroclastic surges of swiftly flowing, dense 
clouds of hot gases, ash, and lava fragments known locally as lawi lawi might sweep silently down the flanks of the volcano and suddenly overwhelm the unsuspecting inhabitants in the lands below. Such was the fate that overcame Barrio Bigaa, an outlying settlement of Legazpi in June 1928, as 'men, women, and children seeking safety, ran pell-mell, carrying what little belongings they could gather together on the spur of the moment, driving before them in all directions domestic animals filling the air with shrieks and howls - a veritable pandemonium'. ${ }^{52}$ Much of the surrounding land is vulnerable to this peril: a pyroclastic density current on 21 April 1968 reached 7 kilometres from the summit and descended to an elevation of 200 metres. $^{53}$

While the temporary need to evacuate existing settlements was seemingly a constant feature of life around the volcano, the site of the towns themselves was often determined by the particular characteristics of Mayon's eruptive phases. While wind direction was always an important determinant in deciding which communities were more at risk than others, successive eruptions did change the contours of the cone's rim and therefore affected the direction lava and lahars might take. Seasonal wind directions in the Philippines are dominated alternatively by the trade winds and the monsoons. Between September/October and May/June, the prevailing wind is from the east (Amihan) and characterised by moderate temperatures with little or no rainfall, but for the rest of the year, the prevailing wind is from the west (Habagat) and characterised by hot and humid weather with frequent heavy rainfall. The exact fallout area of any ash cloud, therefore, reflected when the eruption occurred, with some settlements being more at risk than others at certain times of the year. If seasonal wind directions have not fluctuated dramatically over recent centuries, the likely direction of lava flows and lahars has changed dramatically on several occasions. Towns considered relatively safe when settled might later prove to be in the direct path of oncoming lava and lahars as the height of the cone's sides varied or the channels that ran down the flanks of the volcano 
shifted. Father José Coronas noted just such developments in his treatise on the 1897 eruption of Mayon, observing how the path the lava took had changed over the years. Beginning with a description of the 1814 eruption, the lava had destroyed the towns of Cagsawa, Camalig and Budiao, all situated on the southern side of the volcano. Similarly, the flow of lava had all been to the south and southeast in the 1871, 1881, 1885, 1886 and 1887 eruptions. During the latter eruption, however, the volcano's cone had been modified and, in the eruption of 1890, the lava flowed down the eastern flank of Mayon in the direction of the town of Libog, which had been previously largely spared such danger. ${ }^{54}$

The shifting nature of this threat persuaded entire communities to relocate on occasion. The inhabitants of the doomed town of Cagsawa had petitioned the provincial governor to transfer their town to Daraga in 1771 due to the dangers posed by frequent lahars. ${ }^{55}$ Alas, the relocation was not realised before the deadly eruption of 1 February 1814. This is the first event for which there are detailed records of the course and aftermath of the eruption. Accounts give a harrowing description of its progress and of the deaths of 1,200 residents in nearby settlements. ${ }^{56}$ In all, maybe some 30,000 people were directly affected. However, it is the ensuing debate over the relocation of certain towns that is most illuminating. Three towns - Cagsawa, Camalig and Budiao - were quite literally burnt to the ground, while two others - Guinobatan, and the provincial capital Albay - were badly damaged, though the churches and municipal buildings of both places survived. A new vent had reportedly opened on the volcano's flanks and had proven particularly fatal to the town of Budiao, which had literally been 'erased' from the earth with as many as 200 people alone perishing in the church. ${ }^{57}$

The question of relocation was picked up again with renewed urgency in the aftermath of the disaster. Already by 16 February, the provincial governor of Camerines wrote to the governor general in Manila suggesting that not only the five ruined towns of the 
Iraya be relocated but that the remaining three also be removed to a safer area. ${ }^{58}$ In fact, many local townspeople had already taken matters into their own hands and had moved to new locations. The inhabitants of Camalig, for instance, had settled more than a league (5.5 kilometres) away from the volcano but near enough to their old site that the remaining residents could still use the existing irrigation system to water their new fields. With the support of the local parish priest they petitioned the provincial governor to officially recognise their move and asked, in addition, for relief from tribute and taxation for the next seven years so as to allow them to properly establish a new town. ${ }^{59}$ The inhabitants of Guinobatan petitioned for much the same favours, with their parish priest, Father Francisco Tubino, pointing out how in the space of five and a half hours 'the work of countless years of sweat and toil by their ancestors had been lost' ${ }^{60}$ In the event, the devastated towns of Budiao and Cagsawa were merged into a single settlement and removed to a new site at the village of Daraga much along the lines originally proposed in 1771 . The extreme example of 1814 vividly demonstrates how the volcano exerted an influence over the actual location of settlements, attracting people to establish them in the first place, and then influencing their relocation to alternate sites according to the changing profile of its eruptions.

Not only did the volcano affect the spatial pattern of human settlement but its menacing presence influenced the minds of the people who lived in them. Volcanoes figure in the Bikol folk epic, the Ibálong, the extant verses of which clearly describe some cataclysmic eruption in pre-Hispanic times that caused extensive morphological changes to the surrounding landscape. ${ }^{61}$ Mayon is also the subject of a myth in which a beautiful maiden, Magayón, and her lover are slain on her wedding day, and she is subsequently transformed into the volcano. On days when the volcano’s summit is shrouded in clouds, old people say that the two are kissing. ${ }^{62}$ With Christianity, however, natural hazards were typically depicted as forms of gaba or divine punishment for one’s past actions, or sins that 
fall on the innocent as well as the guilty. ${ }^{63}$ Such is the recurring motif in most pre-twentiethcentury accounts of eruptions which are generally explained in such terms. The 1814 eruption, for example, is accounted for in terms of punishment for some unspecified wrongdoing. A circular from the vicar general of Nueva Caceres distributed shortly after the eruption rationalised the event as a form of 'Divine Justice, angry at our sins', and admonished priests and their congregations to be more prudent in the future. ${ }^{64}$ One of these parish priests, pondering on his own survival, asked 'Who among us thought to remain alive in the face of such clear manifestations of divine Justice?'. ${ }^{65}$ Although these attitudes were beginning to be questioned in the late nineteenth century and to be replaced by more 'scientific' explanations, the notion of a vengeful God persisted. A rare vernacular account, written in Bikol of the 1897 eruption, still refers to it as God's 'way of punishing people'. ${ }^{66}$ Nor have such attitudes completely died out in the contemporary Philippines. ${ }^{67}$

In the 1897 eruption, the volcano even interfered directly in human affairs, influencing the course of events. The eruption took place during a lull in the Philippine Revolution, while that of 1900 occurred during the Philippine American War. ${ }^{68}$ What little is known about the 1900 eruption comes from the report of US soldiers fighting in the Bikol region at the time. Quite apart from commenting on the 'nerve-racking' experience the eruption had on the invading troops as the constant vibrations noisily rattled windows and doors, the volcanic dust seeped into every nook and cranny, contaminating food chests and affecting the reliability of watches and compasses. Even the troops' rifles were rendered inoperative as the bolt mechanisms jammed, making it impossible to reload. Captain Betts wrote how this difficulty only added 'to our already many worries, for if our rifles could not be used we were at the mercy of the bolo men from whom we were expecting an attack in force at any time'. In the event, republican forces had been just as unsettled by the eruption and had moved away from the volcano into the interior as rapidly as possible. American 
soldiers also discovered that by cutting the toe out of a sock, slipping it over the barrel and tying each end around the bolt, there was ample room to empty and reload the magazine before the mechanism clogged again. ${ }^{69}$

\section{SOCIETY’S EFFECT ON VOLCANOES}

More difficult to discern but no less influential is human society’s effect on the volcano. On first consideration, it may be thought that people exert no influence on volcanic activity, and, obviously, the proximity of human settlement has no bearing on the type or timing of eruptions. Mayon lies in a chain of ten, mostly dormant, volcanic cones that form the Bikol Peninsula of south-eastern Luzon. Apart from Mayon, only Bulusan is known to be active, and it has erupted fifteen times since 1885. Most eruptions of Mayon are either Strombolian that is, small to medium in volume and consisting of the ejection of incandescent cinder, lapilli and lava bombs to altitudes of a few hundred metres - or Vulcanian - characterised by a dense cloud of ash-laden gas exploding from the crater and rising high above the peak, dispersing tephra and ash over a wide area of the surrounding countryside and usually ending with a flow of viscous lava. ${ }^{70}$ Human modification of the surrounding landscape, however, has had an influence on the course of eruptions, particularly in determining the direction of lava flows and lahars. Moreover, as human population and activities have intensified over the centuries so has this impact become more pronounced.

The number of people living in Albay province has risen steadily in recent years from approximately 246,000 people in 1887 to a total of 1,314,826 according to the 2015 census. While this represents an annual growth rate of 1.32 per cent over the last century or so, the population has increased two and a half times since $1980 .{ }^{71}$ Earlier population densities are harder to estimate, though the number of people living in the Bikol Peninsula rose from 
146,100 in 1794 to 487,500 by $1887 .^{72}$ The peninsula was a prosperous region, and Father Aragoneses describes how intensive cultivation had reached even to the lower slopes of the volcano by 1814, which had been 'converted into a wide and beautiful garden'. In the doomed town of Budiao, the town site closest to Mayon, the fertile fields yielded coconuts, cacao, abaca, all manner of fruit trees as well as root crops and vegetables. ${ }^{73}$ Enrique Abella y Casariego, the Spanish mining engineer who observed the 1882 eruption, noted how land was regularly cultivated to an altitude of $600 \mathrm{~m}$ on the volcano's flanks. ${ }^{74}$

All this agricultural activity suggests that most of the forested areas had been cleared from around the base of the volcano by the beginning of the nineteenth century. While nothing will prevent pyroclastic density currents and surges or check lahars and debris flows, barriers, whether constructed (concrete dikes and earthen embankments) or natural like forests will temporarily slow their descent and limit the area affected. Similarly, the removal of such barriers or deforestation has the opposite effect. Recent forest clearance on the southern flanks of Semeru Volcano in East Java by Madurese immigrants is blamed for aggravating the damage caused during eruptions and by heavy rainfall. ${ }^{75}$ An absence of trees, moreover, increases the run-off rate of rainwater and augments the number of flash floods that develop into devastating debris flows as a result of the high sediment supply from the clear-felled slopes. ${ }^{76}$ The gradual deforestation of the land around Mount Mayon over the centuries, but especially after 1800, has extended the area affected by all forms of run-off from the volcano and increased the number of people at risk.

On other occasions there are recorded instances of human activity made with the express purpose of diverting lahars or debris-laden flash floods. Valuable commercial farmland was constantly at risk from mudflows, especially during the traditional typhoon season between May and November. Faustino noted, however, how some plantation owners had devised ways and means to minimise the losses from such destructive flows by building 
dikes or dams to protect their properties. While such measures may have limited the damage to their own fields, such constructions only diverted the flow to other properties 'so the destruction was no less' ${ }^{77}$ After the 1984 eruption, too, the Japanese International Cooperation Agency constructed a number of sabo dams in downslope areas in an attempt to mitigate the destructive flow of lahars during heavy rains. These have been subsequently rendered ineffective and abandoned (Figure 2) due to the constantly changing nature of the channels down the volcano's flanks and the increased rate of sedimentation. ${ }^{78}$

FIG>Figure 2 near here

At other times, the effects of human ingenuity have had a more incidental but no less destructive impact on influencing the progress of eruptions. Under the American colonial administration, major infrastructural works were carried out both to promote trade and industry and facilitate the movement of troops and the Philippine constabulary. In particular, all-weather roads and a railway were built to connect Manila with the provinces; the road and railway connecting Albay (now known as Legazpi) skirted around the base of the volcano, crossing each other at certain points. Not only did these excavations act as artificial 'channels' directing the paths that the lahars and debris-flows took but they also inadvertently created barriers that constrained or steered such flows toward unintentional 'natural' breaches at crossroads or other similar junctions. In the process, potentially lethal choke points were created where people, traffic and lahars might converge. At other times, lines of communication might be cut for months or even years by the boulders, sand, gravel and other volcanic debris washed down from the mountain. The road to Libog, for instance, damaged in the 1897 eruption, was only finally reopened in $1912 .{ }^{79}$ Even today, as an interview with a senior civil engineer in the local office of the Department of Public Works and Highways 
confirmed, little consideration is given to such matters in the planning or construction of the modern road network. ${ }^{80}$

Finally, the way humans have thought about the volcano has also changed, especially over the last century, and, in the process, this has had some bearing on the course of subsequent eruptions. There was a move to relocate the population immediately surrounding the volcano after the 1928 eruption, limiting the entry of future homesteaders and declaring Mayon a public park. ${ }^{81}$ In the event, the volcano was made a forest reserve in 1932, then declared a national park in 1938 by President Quezon before being proclaimed as Mayon Volcano Natural Park in 2000. Such designations, however, have not altogether prevented illegal settlers from farming its slopes. PHIVOLCS, too, as part of its disaster management strategy, has designated a Permanent Danger Zone (PDZ) 6 kilometres wide around the volcano in which farmers and residents are advised to cease all activity in the event of an eruption. This zone is further extendable to 8 kilometres in the high-risk area to the southeast of the volcano, from which residents are evacuated in times of alert. ${ }^{82}$ As notions of conservation and risk have changed over the twentieth century, prompting a reappraisal of who can live close to the volcano and what activities they can pursue, there has been a moderate rewilding of Mayon's flanks, perhaps with consequent effects upon more recent eruptions.

\section{CONCLUSION}

The history of the Philippines, as anywhere else, is largely shaped by the interrelationship between the natural and the human, of the physical and the social. Susanna Hoffman and Anthony Oliver-Smith refer to this human-environmental interaction in terms of 'mutuality', where outcomes are determined by both factors acting upon each other. ${ }^{83}$ Both the culture of 
the society and the nature of the environment are the product of a long-term interaction over time. In order to understand the measure of this interaction, the risk so to speak, there is a need, as Susan Stonich so aptly phrases it, to 'balance the cultural/social construction of nature with a meaningful consideration (and analysis) of the natural construction of the cultural and social' ${ }^{84}$ Around Mayon, this mutuality is expressed in terms of a co-volcanic society, where the mountain helps shape the culture of the human society around it, and the human society, in its turn, exerts an influence on the topography of the mountain and its natural processes. Disasters occur in this relationship 'at the intersection of nature and culture and illustrate, often dramatically, the mutuality of each in the constitution of the other' ${ }^{85}$

The hallmark of a co-volcanic society depends on whether eruptions have had a significant effect on the culture of the communities living around volcanoes and whether human activities have impacted upon their natural processes. As regards the former, it is not difficult to discern the effect of the volcano on local culture, whether as regards the actions taken that are more directly attributable to an eruption, or where disasters have acted more as a catalyst of change in the longer term. Archaeological evidence suggests that the key variable in this respect is not magnitude but frequency. Disasters which occur frequently over relatively long periods of time can instigate adaptation and engender cultural change or, alternatively, they may retard any such developments. In this respect, disasters are perceived not so much as purely natural events but also as social ones that are explained or refuted according to how a threat is interpreted through a specific cultural and temporal lens. ${ }^{86}$ Unlike many other volcanoes in the Philippines that erupt irregularly at intervals of several centuries, Mayon is almost constantly in eruption. Faustino, for instance, estimated that there was an eruption about every four years, an average that still holds true depending on whether you include very small events. ${ }^{87}$ Here, then, are the three factors identified by Wenger and Weller as crucial to the emergence of a disaster subculture: Mayon erupts repetitively; the 
nature of these eruptions is mainly but not always heralded by a series of micro earthquakes, volcanic tremors, subterranean noises and an incandescent dome; and the consequences of these eruptions cause significant damage to human and material resources, most notably in 1814 and 1897. In the archipelago, only Taal Volcano proffers a similar profile.

However, a co-volcanic society is one where the hazard not only exerts an influence on human society but also one where the actions of that society affect the natural processes of the hazard. Here, of course, the evidence is more tentative and requires deeper research that may have to delve beyond the confines of the archival and documentary and involve the collaboration of volcanologists, geographers and soil scientists amongst others. But even in the documentary record, there is sufficient evidence to suggest that human activities and the way people have thought about the volcano has had some influence on, at least, how eruptions took place. Human activity and perceptions have modified the environment and the topography around the volcano, and thereby influenced in some measure the direction and extent of pyroclastic density currents, lahars and debris flows. ${ }^{88}$ To some extent, at least, volcanic eruptions, or the manner in which they occur, are also social constructions.

Over the centuries, society and environment have adapted to one another to create a co-volcanic society around Mount Mayon. By drawing attention to the mutuality between society and environment, the concept of co-volcanic societies has important considerations for both historiography and contemporary disaster risk reduction (DRR) in the Philippines. As regards historiography, the notion of co-volcanic societies explores the ways in which environmental factors help shape the course of human history as well as highlighting the historical role of humans in modifying environmental processes. The volcano must loom large in any history of the region that is shaped not just by human activity but also by natural processes. Historically, the population of Albay has been governed by the dynamics of diametrically opposing forces: the menace of the volcano that drives people away from the 
hinterland towards the coast on the one hand, and the threat of Moro raiders whose depredations forced people to abandon the coast for the safety of settlements further inland on the other. How exactly these forces have shaped settlement patterns in Albay is beyond the scope of this article but certainly worthy of further consideration. The concept of co-volcanic societies reveals how risk is not simply a product of human social structures (that is, the power relations within society) but also the outcome of 'natural structures' (the balance of forces within the physical world).

Also, by drawing attention to the importance of culture in determining people’s behaviour in the face of danger, the concept of co-volcanic societies has important applications for contemporary DRR in the Philippines. In the first place, it reveals the compound nature of risk, that it is both the product of the interaction between the physical world and human activity. Second, it highlights the importance of the local, the specific, the situational and the contextual, emphasising, in particular, the importance of historical considerations to any understanding of vulnerability and so to DRR. Third, it questions the validity of terminological classifications. As Mayon quite clearly illustrates, 'volcanoes ain't volcanoes'; that is, some volcanoes are very active and the risk posed by them very much depends on how frequently they erupt. Classifying volcanoes as either active or dormant or by their structure and composition (strato, dome, shield and cinder) pays insufficient attention to the human dimension. And, finally, thinking about societies as co-volcanic highlights how vulnerability is the product of culture. Culture or the way people perceive the world around them and act according to traditional patterns of behaviour over time should be a significant factor in determining the success of any measures taken to reduce risk. ${ }^{89}$ As Faustino observed shortly after the 1928 eruption of Mayon: 
The trees and plants damaged in July have recovered and once more the plains and slopes of Mayon are covered with green vegetation. People have returned to their homes, and the disturbance which caused no little commotion and mobilised all the government forces and the Philippine Chapter of the Red Cross has settled down - to wait for the next eruption. ${ }^{90}$

As the history of the communities around Mount Mayon shows, societies that live under a volcano form part of a single interdependent system, each influencing the other, that together co-evolve over time.

\footnotetext{
${ }^{1}$ Weather conditions on the battlefield of Waterloo, particularly the muddy terrain caused by heavy rains attributed to the volcanic ash in the atmosphere from the massive eruption of Tambora a few months earlier, have been blamed for delaying Napoleon's attack on Wellington’s position and for hampering his troops’ frontal uphill assault. Dennis Wheeler and Gaston Demarée, 'The weather of the Waterloo campaign 16 to 18 June 1815: Did it change the course of history?' Weather 60, 6 (2005): 159-64.

${ }^{2}$ Shannon Doocy, Amy Daniels, Shayna Dooling and Yuri Gorokhovich, 'The human impact of volcanoes: A historical review of events 1900-2009 and systematic literature review’, PLOS Currents: Disasters, 16 April 2013 (available at:
} http://currents.plos.org/disasters/article/the-human-impact-of-volcanoes-a-historical-reviewof-events-1900-2009-and-systematic-literature-review/).

${ }^{3}$ Christopher Small and Terry Naumann, 'Holocene volcanism and the global distribution of human population', Environmental Hazards 3, 3/4 (2001): 93-109.

${ }^{4}$ Carla Galeazzi, Carlo Germani and Luigi Casciotti, 'The drainage tunnel of Lake Albano (Rome, Italy) and the 3-year’s study program “Project Albanus”: A progress report’, p. 180. Paper given at the International Congress of Speleology in Artificial Cavities Hypogea, 11- 
17 March 2015 (available at:

file://C:/Users/Study/Downloads/The_drainage_tunnel_of_Lake_Albano_Rome\%20(2).pdf, accessed 21 October 2016). See also Dmitri Rouwet, Giovanni Chiodini, Cecilia Ciuccarelli, Alberto Comastri and Antonio Costa, 'Lago Albano, the "anti-Nyos-type” lake: The past as a key for the future', Journal of African Earth Sciences 150 (2019): 425-50.

${ }^{5}$ Matthias Garschagen, Peter Mucke, Almuth Schauber, Thomas Seibert, Torsten Welle, Jörn Birkmann and Jakob Rhyner, 'World risk report', Bündnis Entwicklung Hilft/United Nations University Institute for Environment and Human Security, 2014 (available at:

https://i.unu.edu/media/ehs.unu.edu/news/4070/11895.pdf), p. 64.

${ }^{6}$ Harry Estill Moore, And the Winds Blew (Austin, TX: Hogg Foundation for Mental Health, 1964), p. 195.

${ }^{7}$ Dennis E. Wenger and Jack M. Weller, 'Disaster subcultures: The cultural residues of community disasters’, Disaster Research Centre Preliminary Paper No. 9 (Columbus:

Disaster Research Centre, Ohio State University, 1973), p. 1.

${ }^{8}$ Ibid., 2-5, 9.

${ }^{9}$ Greg Bankoff, 'Design by disasters: Seismic architecture and cultural adaptation to earthquakes’, in Fred Krüger, Greg Bankoff, Terry Cannon, Benedikt Orlowski, E. Lisa and F. Schipper (eds), Cultures and Disasters: Understanding Cultural Framings in Disaster Risk Reduction (London: Routledge, 2015), pp. 53-71.

${ }^{10}$ Gregory Clancey, Earthquake Nation: The Cultural Politics of Japanese Seismicity, 18681930 (Berkeley: University of California Press, 2006).

${ }^{11}$ Jacqueline Homan and Warren J. Eastward, ‘17 August 1999 Kocaeli (Izmit) earthquake: Historical records and seismic culture', Earthquake Spectra 17, 4 (2001): 624.

${ }^{12}$ Dorothy B. Vitaliano, Legends of the Earth: Their Geological Origins (Bloomington: Indiana University Press, 1973). 
${ }^{13}$ Katherine V. Cashman and Shane J. Cronin, 'Welcoming a monster to the world: Myths, oral tradition, and modern societal response to volcanic disasters', Journal of Volcanology and Geothermal Research 176 (2008): 408-9.

${ }^{14}$ Mark G. Elson, Michael H. Ort, Kirk C. Anderson and James M. Heidke, 'Living with the volcano: The 11th Century AD eruption of Sunset Crater', in John Grattan and Robin Torrence (eds), Living under the Shadow: The Cultural Impacts of Volcanic Eruptions (Walnut Creek, CA: Left Coast Press, 2007), pp. 107-31.

${ }^{15}$ Michael R. Dove, 'Perception of volcanic eruption as agent of change on Merapi Volcano, Central Java’, Journal of Volcanology and Geothermal Research 172 (2008): 333. ${ }^{16}$ Ibid., 36.

${ }^{17}$ Katherine Donovan, 'Doing social volcanology: Exploring volcanic culture in Indonesia', Area 42, 1 (2010): 117-26.

${ }^{18}$ S.K. Brown, M.R. Auker and R.S.J. Sparks, 'Populations around Holocene volcanoes and development of a population exposure index', in Susan C. Loughlin, Steve Sparks, Sarah K. Brown, Susanna F. Jenkins and Charlotte Vye-Brown (eds), Global Volcanic Hazards and Risk (Cambridge: Cambridge University Press, 2015), p. 224. The Philippines (82 per cent), Indonesia (84 per cent) and Japan (89 per cent) are the countries with the greatest number of people living in close proximity to volcanoes, though Guatemala and Iceland, with much smaller total populations, have over 90 per cent of their population living in such areas. ${ }^{19}$ Raymundo Punongbayan, 'Natural hazards in the Philippines', in Proceedings of the National Conference on Natural Disaster Mitigation, 19 to 21 October 1994 (Quezon City: DOST-PHIVOLCS, 1994), p. 5.

${ }^{20}$ Greg Bankoff, Cultures of Disaster: Society and Natural Hazard in the Philippines (London: Routledge, 2003), pp. 179-83; Official Poverty Statistics 2012 (Makati: National Statistical Coordination Board, 2014), available at: http://www.nscb.gov.ph/poverty. 
${ }^{21}$ PHIVOLCS, 'List of active and inactive volcanoes’, Philippine Institute of Volcanology and Seismology, 30 July 2008 (available at:

http://www.phivolcs.dost.gov.ph/index.php?option=com_content\&view=article\&id=57:activ e-volcanoes\&catid=55\&Itemid=114, accessed 26 October 2016).

${ }^{22}$ Thomas R. Hargrove, The Mysteries of Taal: The Philippine Volcano and Lake, Her Sea Life and Lost Towns (Manila: Bookmark Publishing, 1991).

${ }^{23}$ Jors van Spilbergen, The East and West Indian Mirror: Being an Account of Joris van Spilbergen's Voyage Round the World (1614-1617), and the Australian Navigation of Jacob Le Maire (London: Hakluyt Society, 1906), p. 118.

${ }^{24}$ Félix de Huerta, Estado geográfico, topográfico, estadístico, histórico religioso: De la santa y apostólica provincia de S. Gregorio Magno, de religiosos menores descalzos de la regular y más estrecha observancia de N.S.P.S. Francisco, en las Islas Filipinas (Binondo: M. Sanchez y Ca., 1865), p. 255; Guillaume J.H. J-B Le Gentil, A Voyage to the Indian Seas (Makati, Rizal: Filipino Book Guild, 1969), p. 9.

${ }^{25}$ Mérito B. Espinas, ‘Eruptions of Mayon’, Unitas 41, 2 (1968): 253.

${ }^{26}$ José Coronas, The Eruption of Mayon Volcano June 25, 26, Year 1897 (Manila: Private Printing Press of the Observatory, 1898), p. 4 (unpublished manuscript, PHIVOLCS Library, Quezon City, MO90).

${ }^{27}$ Interview with 86-year-old informant, Santo Domingo, 20 January 2018. The interviewee was evidently not alive in 1897 but graphically remembers the stories told her about the eruption by her grandmother in the 1930s.

${ }^{28}$ Leopoldo A. Faustino, 'Mayon Volcano and its eruptions', Philippine Journal of Science 40, 1 (1929): 23. 
${ }^{29}$ Espinas, 'Eruptions of Mayon', 251-2; Maria Hannah Terbio Mirabueno, 'Reconstruction of the 01 February 1814 eruption of Mayon Volcano, Philippines’ (MSc diss., University of Canterbury, New Zealand, 2001), pp. 4-7.

${ }^{30}$ More minor eruptions occurred in 1900, 1902, 1928, 1938, 1939, 1941, 1943, 1947, 1968 (six killed) and 1978 (no casualties but 23,000 evacuated). Haraldur Sigurdsson, Bruce Houghton, Hazel Rymer, John Stix, Steve McNutt, Encyclopedia of Volcanoes (New York: Academic Press, 1999), p. 1373.

31 'Albay Province, Philippines: Coexisting with Mayon Volcano and countermeasures for disaster preparedness', Asian Disaster Management News 8, 4 (2002) (available at: www.reliefweb.int/w/rwb.nsf/0/9bf979b1b1079d985256ca3005caef7?OpenDocument, accessed 28 October 2016).

${ }^{32}$ Giovanni Rantucci, Geological Disasters in the Philippines: The July 1990 Earthquake and the June 1991 Eruption of Mount Pinatubo (Rome: Dipartimento per l'Informazione e l’Editoria, 1994), pp. 97, 100.

${ }^{33}$ Le Gentil, Voyage to the Indian Seas, 9-10. There is some confusion over whether this event took place in 1766 or 1776 and whether the eruption and the lahar were separate or related events. The authenticity of Le Gentil's account has been called into question on more than one occasion and Faustino clearly identifies the event as occurring in 1766, though it is not clear on what grounds he makes this assumption. Faustino, 'Mayon Volcano', 11.

${ }^{34}$ Enrique Abella y Casariego, 'El Mayon, or the volcano of Albay (Philippines) 1 April 1882’ (unpublished manuscript, PHIVOLCS Library, PL M001), p. 3.

${ }^{35}$ Faustino, 'Mayon Volcano’, 11.

${ }^{36}$ Ibid., 3.

${ }^{37}$ Louis Bacani, 'Deadliest, most destructive cyclones of the Philippines', Philippine Star, 11 November 2013 (available at: 
https://www.philstar.com/headlines/2013/11/11/1255490/deadliest-most-destructivecyclones-philippines).

${ }^{38}$ Robert Singg, ‘The beauty of Mayon', Mid-Pacific 50, 1 (July 1930): 67.

${ }^{39}$ Faustino, 'Mayon Volcano’, 10.

${ }^{40}$ Vince E. Neall, 'Volcanic soils’, in Willy H. Verheye (ed.), Land Use, Land Cover and Soil Sciences: Encyclopedia of Life Support Systems (Oxford: EOLSS Publishers, 2009), pp. 23-45.

${ }^{41}$ Elson et al., 'Living with the volcano', 118.

${ }^{42}$ Fedor Jagor, Travels in the Philippines (London: Chapman and Hall, 1875), p. 91.

${ }^{43}$ Faustino, ‘Mayon Volcano’, 14.

${ }^{44}$ Norman G. Owen, Prosperity without Progress: Manila Hemp and Material Life in the Colonial Philippines (Berkeley: University of California Press, 1984).

${ }^{45}$ Singg, 'The beauty of Mayon', 71.

${ }^{46}$ Faustino, 'Mayon Volcano', 30, 38.

${ }^{47}$ Miguel Selga, 'The eruption of the Mayon in 1900' (unpublished manuscript, Archives of the Manila Observatory (AMO), box 13, file 2/3), p. 21.

${ }^{48}$ Donald W. Peterson, 'Volcanoes: Tectonic setting and impact on society', in National Research Council, Active Tectonics: Impact on Society (Washington, DC: National Academies Press, 1986), p. 239.

${ }^{49}$ Faustino, 'Mayon Volcano’, 25.

${ }^{50}$ Singg, ‘The beauty of Mayon', 70.

${ }^{51}$ Selga, 'The eruption of the Mayon in 1900', 10.

52 Faustino, ‘Mayon Volcano’, 26.

53 J.G. Moore and William G. Melson, 'Nueés ardentes of the 1968 eruption of Mayon Volcano, Philippines', Bulletin of Volcanology 33 (1969): 600-620. 
${ }^{54}$ Coronas, Eruption of Mayon Volcano,18.

${ }^{55}$ Francisco Mallari S.J., 'Cagsawa: The tragic town in the Bicol Peninsula and the failed attempt to transfer the townsite before the catastrophe of 1814', Kinaadman 8 (1986): 19-34. 56 This number may have been inflated by Aragoneses as it suggests that nearly 20 per cent of the local population died in the eruption, a somewhat exceptional figure. Francisco Aragoneses, Suceso espantoso acaecido en la erupcion del Volcan de Alba en la Isla de Luzon, una de las Llamadas Filipinas (Madrid: Imprenta de Nuñez, 1815). Aragoneses’s account was primarily written to solicit charity in Spain for the affected towns, and a higher death toll may have seemed justified in the circumstances. Interview with local historian, Camalig, 17 January 2018.

57 [Miguel Selga], 'La erupción del Mayón en 1814 y el traslado de algunos pueblos de la Iraya’ (unpublished manuscript, AMO, box 13, file 2/4), p. 20. This manuscript is compiled by Miguel Selga and contains 24 first-hand accounts of the eruption and its aftermath, the originals of which may no longer exist. Each account is given verbatim and in whole and preceded by a brief summary of its contents by Selga.

${ }^{58}$ Ibid., 20.

${ }^{59}$ Ibid., 25-8.

${ }^{60}$ Ibid., 38.

${ }^{61}$ Mérito B. Espinas, ‘A critical study of Ibálong, the Bikol folk epic-fragment', reprinted from Unitas (University of Santo Tomas) 41, 2 (1968): 30-31. See also Mérito B. Espinas, Ibalong, the Bikol Folk Epic Fragment: English and Bikol Translation, Views and Comments (Legaspi City: M.C. Espinas, c.1996).

${ }^{62}$ Mérito B. Espinas, ‘The legend of Dalagang Magayón’, Unitas 41, 2 (1968): n.p., reprinted in 1969. 
${ }^{63}$ Lilian C. Garcia, ‘Some observations of the Gaba phenomenon', Philippine Quarterly of Culture and Society 4, 1 (1976): 31-6.

${ }^{64}$ Miguel Selga, 'La erupción del Mayón en 1914 y el vicario general de Nueva Caceres’ (unpublished manuscript, PHIVOLCS Library, MO57).

${ }^{65}$ Aragoneses, Suceso espantoso, 13.

${ }^{66}$ Mariano, Perfecto, Bareta dapit can Volcan Mayong sa Albay can Junio de 1897 (Nueva Caceres: Imprenta ‘La Sagrada Familia’, 1897), pp. 16-17.

${ }^{67}$ Greg Bankoff, 'In the eye of the storm: The social construction of the forces of nature and the climatic and seismic construction of God in the Philippines', Journal of Southeast Asian Studies 35, 1 (2004): 91-111.

${ }^{68}$ Elias Ataviado, The Philippine Revolution in the Bicol Region, Vol. 1: From August 1896 to January 1899 (Manila: Encal Press, 1953), pp. 52-55.

${ }^{69}$ Selga, 'The eruption of the Mayon in 1900', 18-19.

${ }^{70}$ Christopher G. Newhall, 'Temporal variation in the lavas of Mayon Volcano, Philippines', Journal of Volcanology and Geothermal Research 6, 1/2 (1979): 61-83.

${ }^{71}$ Jan Lahmeyer, 'The Philippines: Historical demographical data of the administrative division’, Population Statistics, 2002 (available at: http://www.populstat.info/Asia/philippp.htm, accessed 2 November 2016); Philippine Statistics Authority, 'Population of Region V - Bicol (based on the 2015 census of population)', 4 June 2016 (available at: https://psa.gov.ph/content/population-region-v-bicolbased-2015-census-population, accessed November 2016).

${ }^{72}$ Owen, Prosperity without Progress, 116.

${ }^{73}$ Aragoneses, Suceso espantoso, 7-8.

${ }^{74}$ Abella y Casariego, 'El Mayon', 9. 
${ }^{75}$ Frank Lavigne and Yanni Gunnell, 'Land cover change and abrupt environmental impacts on Java and volcanoes, Indonesia: A long-term perspective on recent trends’, Regional Environmental Change 6 (2006): 91.

${ }^{76}$ Interview with local volcanologist, Salvacion, 20 January 2018.

${ }^{77}$ Faustino, ‘Mayon Volcano’, 11.

${ }^{78}$ Charlotte Benson, 'The economic impact of natural disasters in the Philippines', ODI Working Paper No. 99 (London: Overseas Development Institute, 1997).

${ }^{79}$ Faustino, 'Mayon Volcano', 41; Ataviado, The Philippine Revolution, 55.

${ }^{80}$ Interview with Department of Public Works and Highways civil engineer, Legazpi, 23 January 2018.

${ }^{81}$ Faustino, ‘Mayon Volcano’, 41-2.

${ }^{82}$ Greg Bankoff and Dorothea Hilhorst, 'The politics of risk in the Philippines: Comparing state and NGO perceptions of disaster management', Disasters 33, 4 (2009): 693-4.

${ }^{83}$ Susanna Hoffman and Anthony Oliver-Smith, ‘Anthropology and the angry earth: An overview', in Anthony Oliver-Smith and Susanna Hoffman (eds), The Angry Earth: Disaster in Anthropological Perspectives (London: Routledge, 1999), p. 6.

${ }^{84}$ Susan Stonich, ‘Comments’, Current Anthropology 40, 1 (1999): 23-4.

${ }^{85}$ Anthony Oliver-Smith, 'Theorizing disasters: Nature, culture, power’, in Susanna M. Hoffman and Antony Oliver-Smith (eds), Catastrophe in Culture: The Anthropology of Disaster (Santa Fe, NM: School of American Research Press, 2002), p. 24.

${ }^{86}$ Robin Torrence and John Grattan, 'The archaeology of disasters: Past and future trends', in Robin Torrence and John Grattan (eds), Natural Disasters and Cultural Change (London: Routledge, 2002), pp. 11-13.

${ }^{87}$ Faustino, ‘Mayon Volcano’, 34; Communication from local volcanologist, Salvacion, 15 November 2018. 
${ }^{88}$ A.W. Woods, M.I. Bursik and A.V. Kurbatov, 'The interaction of ash flows with ridges', Bulletin of Volcanology 60, 1 (1998): 38-51.

${ }^{89}$ Terry Cannon, Lisa Schipper, Greg Bankoff and Fred Krueger (eds), 'World disaster report 2014: Focus on culture and risk’ (Geneva: International Federation of the Red Cross and Red Crescent Societies, 2014).

${ }^{90}$ Faustino, ‘Mayon Volcano’, 34, emphasis added. 